\title{
Decision Support for the (Inter-)Basin Management of Water Resources Using Integrated Hydro-Economic Modeling
}

\author{
Gerald Norbert Souza da Silva ${ }^{1, *}$ and Márcia Maria Guedes Alcoforado de Moraes ${ }^{2}$ \\ 1 Department of Civil and Environmental Engineering, Federal University of Paraiba, \\ João Pessoa PB 58051-900, Brazil \\ 2 Department of Economics, Federal University of Pernambuco, Recife PE 50740-590, Brazil; \\ marcia.alcoforado@ufpe.br \\ * Correspondence: gerald.silva@academico.ufpb.br; Tel.: +55-83-99992-9405
}

Citation: Souza da Silva, G.N.; Alcoforado de Moraes, M.M.G. Decision Support for the (Inter-)Basin Management of Water Resources Using Integrated Hydro-Economic Modeling. Hydrology 2021, 8, 42. https://doi.org/10.3390/hydrology 8010042

Received: 4 February 2021

Accepted: 2 March 2021

Published: 5 March 2021

Publisher's Note: MDPI stays neutral with regard to jurisdictional claims in published maps and institutional affiliations.

Copyright: (c) 2021 by the authors. Licensee MDPI, Basel, Switzerland. This article is an open access article distributed under the terms and conditions of the Creative Commons Attribution (CC BY) license (https:// creativecommons.org/licenses/by/ $4.0 /)$.

\begin{abstract}
The development of adequate modeling at the basin level to establish public policies has an important role in managing water resources. Hydro-economic models can measure the economic effects of structural and non-structural measures, land and water management, ecosystem services and development needs. Motivated by the need of improving water allocation using economic criteria, in this study, a Spatial Decision Support System (SDSS) with a hydro-economic optimization model (HEAL system) was developed and used for the identification and analysis of an optimal economic allocation of water resources in a case study: the sub-middle basin of the São Francisco River in Brazil. The developed SDSS (HEAL system) made the economically optimum allocation available to analyze water allocation conflicts and trade-offs. With the aim of providing a tool for integrated economic-hydrological modeling, not only for researchers but also for decision-makers and stakeholders, the HEAL system can support decision-making on the design of regulatory and economic management instruments in practice. The case study results showed, for example, that the marginal benefit function obtained for inter-basin water transfer, can contribute for supporting the design of water pricing and water transfer decisions, during periods of water scarcity, for the well-being in both basins.
\end{abstract}

Keywords: spatial decision support system; hydro-economic model; efficient water allocation; interbasin water transfer; economic water values; optimal economic allocation

\section{Introduction}

Economic growth remains important in the alleviation of poverty and remains a goal despite the pressure imposed by the ever-increasing demand for natural and, especially, water resources. Sustainable economic growth, as well as the desired environmental conditions will depend on proper water allocation. Efficient water allocation from a standpoint of economics (economical optimum) is a challenge for integrated water resource management. It is a challenge for managers, users and researchers, mainly due to the increasing demand for water, especially in places where there is relative scarcity [1,2].

Since the first applications of simulation and optimization models were applied to water resources, objectives and economic constraints have been common [3,4]. However, the integration of economic and hydrological aspects, especially in studies aimed at evaluating alternatives and policies for water allocation, inherently involves a series of difficulties $[5,6]$. The two existing strategies to integrate economic and hydrological components in optimization models are: "compartmented modeling" and "holistic modeling". In the former, hydrological and economic components are dealt with as sub-models whose individual solutions are modified by a coordination method to integrate them. In the latter, model components are closely connected into one in such a way that data between them occurs endogenously. 
The compartmented modeling approach was greatly used for large and complex systems due to the fact that, to solve each segment was easier than to solve the entire model. The difficulty was to obtain a method of coordination of these compartmented to produce a solution for the entire model. In the holistic modeling, model components are closely connected into one in such a way that data between them occurs endogenously. The difficulty was to obtain solutions for large models, solutions that could not always be found in the existing software and required that the level of detail and complexity be reduced to adopt this latter approach. In this sense, decomposition methods for the holistic approach had been proposed [7] and were, in turn, the answer to this dilemma. This endogenous treatment of hydrological and economic relationships brought several advantages such as (adapted from Cai [8]): (i) more effective economic-environmental analysis; (ii) ability to capture the relationship between man and the environment; (iii) provision of decision support related to sustainable economic development. Holistic optimization models (integrated water resources optimization models or IWROMs) [9], water resources-economic optimization [8] or hydro-economic models [10]), whose goal is to find the most efficient strategies for water allocation from the economic point of view, while incorporating hydrological and environmental restrictions, have been advancing rapidly and significantly impacting conceptual approaches and water resources management practices [11-20].

A systematic review of publications related to economic models to support water management [21] classified the already mentioned IWROMs into economic models based on a network structure of nodes and links [10,22]. They were different from the more traditional economic models (economywide models) such as input-output models (IOM) and computable general equilibrium (CGE) [23-25]. These latter are models with broader impacts but lack good spatial and hydrological representations for supporting water allocation decisions. As based on a network, IWROMs or hydro-economic models can spatially represent the main components of water systems, being able to integrate hydrological and economic information, and are especially useful at basin scale.

The examination of existing basin-level models and decision support systems (DSS) for public water allocation policies [26], provided a systematic review of the literature on those tools, based on economic/social welfare optimization, social equity, ecological sustainability and quantity-quality management (definition of integrated water resources management-IWRM [27]). There is lack of hydro-economic models capable of evaluating the effects of the application of management instruments on important social welfare indicators such as job and income generation in different social strata. This result stressed the need of integrating the two types of economic models of water management: those of economic optimization (network-based economic models) and the most comprehensive (economywide models) models to support the management of water resources, in agreement with Bekchanov et al. [21].

This strategy should expand the applicability and utility of hydro-economic models, as the integration can expand the capacity for measuring the effects of different allocation policies, supporting their design and evaluation by considering important social welfare indicators. Furthermore, also in relation to the integration of water quality aspects into economic components, many authors $[21,26,28,29]$ noted that progress in the development of hydro-economic models that included these quality aspects remains limited and slow, attributing this to the complexity underlying the dynamics of water quality. Another important observation made was that few studies providing hydro-economic allocation models were found being made available through decision support systems (DSS). They reported those automated systems, mostly, introducing models that consider only engineering criteria: ecological sustainability and quantity-quality (QQ) management.

In the context of water resources management and planning, DSSs have been used extensively in conjunction with (GIS) and given the name, spatial decision support systems (SDSS). In the case of hydro-economic optimization modeling, which is considered a privileged tool for the implementation of an IWRM, the representation of hydrological, environmental and economic aspects in a single platform is very important, an integration 
that can be provided by an SDSS. According to McKinney et al. [30] numerous strategies for coupling models with GISs can be used, ranging from weak coupling to strong coupling. A coupling in which only data between models and GIS is transferred is considered weak and is based on separate systems and generally separate data management. Strong coupling is characterized by integrated data management, in which GIS and models share the same database. The strength of the coupling lies in the fact that data and modeling share the same platform [31-33].

Hydro-economic models being made available through SDSSs can increase the potential and application in IWRM. These systems present, in most cases, a well-developed friendly interface and enabling the integration/application of other models/tools. Furthermore, they can use different decision criteria and restrictions together with the analysis of scenarios/sensitivity. This greatly facilitates and enhances their use by decision makers and stakeholders, favoring an environmentally sustainable management of water resources.

The HEAL system provides hydro-economic modeling (economical optimization criteria) available through a SDSS. Our proposed framework with strong coupling can integrate hydrological, environmental, and economic data to an optimization modeling. The ease and flexibility of defining, modifying, and visualizing any basin in a GIS interface influences the modeling and analysis. Using the platform makes it possible to create specific applications (as the one presented in this study), which can also be modified with the direct cooperation of the decision-maker. At the same time, responses to changes can be easily analyzed and compared, for example, different optimization criteria and other constraints such as water quality or institutional restrictions. The system is an important tool for supporting decisions regarding IWRM, as it can provide a common framework for modelers, decision-makers and stakeholders. Besides, the platform has potential to integrate other water-economy models, such as IOM and CGEM. The economical decision tool and results can be effectively used for setting water stakeholder engagement activities worldwide, and particularly in developing countries.

\section{Materials and Methods}

The Hydro Economic Allocation (HEAL) system was developed for integrated water resource management within an open model platform, including geoprocessing tasks and water user-related data management. The system made it possible to analyze the optimal hydro-economic water allocation, through a link from geoprocessing to the generic optimization modeling system (GAMS) [33], which uses water demands and calculates economic benefits and costs of water users. To validate the model, the HEAL System was applied in a case study to determine the optimal water allocation of main users in the Sub-middle region of the São Francisco river basin, with focus on inter-basin water management.

\subsection{GIS and DSS Integration}

Many challenges are associated with integrating a GIS with models into specific applications. Our SDSS) strongly couples dedicated hydro-economic models with a webbased geographic information system (GIS) environment for integrated water resource management. This is described below, as well as one case study implemented using the HEAL system. Figure 1 shows an overview of the system integration.

The HEAL system was developed using the ArcGIS JavaScript API [34] as interface, the programming interface (API) combines web technology and geospatial capabilities that allow the creation of applications and views of data. The developed hydro-economic model uses the graph theory, in which the water flow is simulated through a directed graph from one node to another. A key point in developing the HEAL system was the development of a hydro-economic network of nodes and links, used for integrating hydrological and economic information directly into the web GIS platform. For the HEAL system, the ArcGIS Geometric Network [35] was chosen as the most appropriate framework. The web edition uses the classes provided for the basic elements of the geometric network, such 
as points (nodes) and lines (links). The main elements of the network in HEAL system are stream nodes, inflow nodes, reservoir nodes, user nodes and links (which connect the nodes logically).

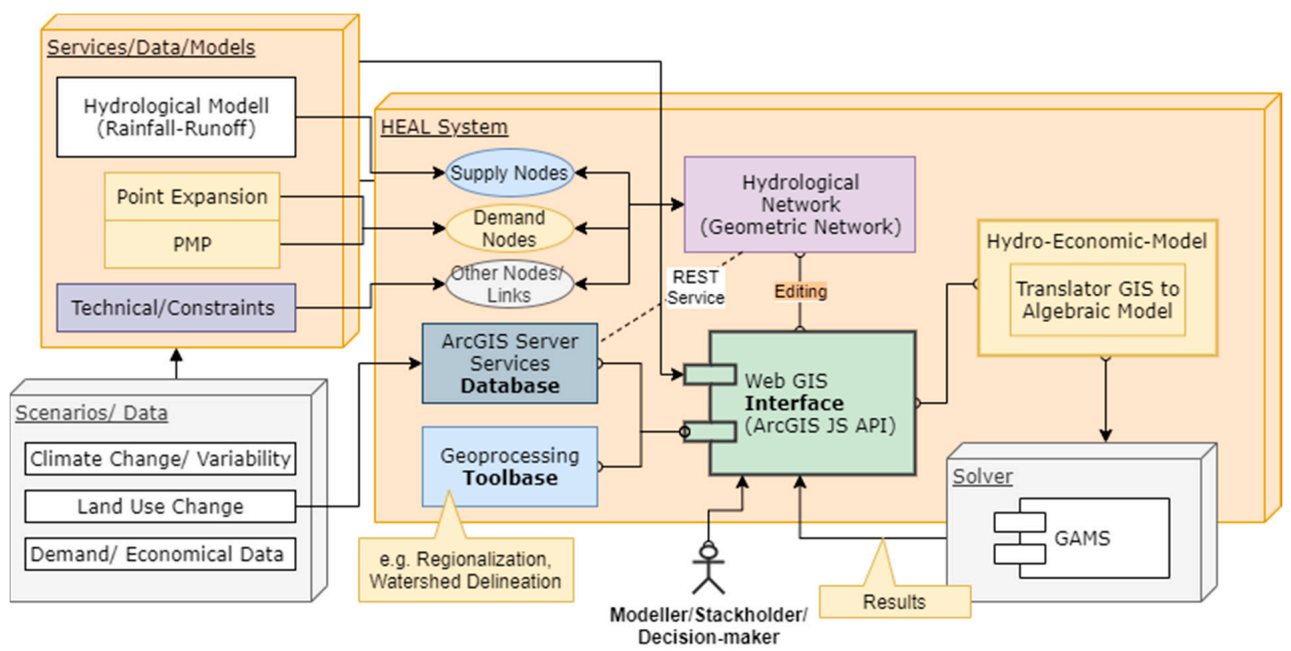

Figure 1. Flow chart GIS, DSS and Hydro-Economic-Model Integration using the HEAL System.

\subsection{The Hydro-Economic Model}

From the spatial representation of the network, a mathematical programming model is constructed automatically for GAMS (solver) [33] using the HEAL system (see Figure 1) to identify optimal water allocation between different water uses, maximizing the net social benefit function, obtained through the aggregation of individual net benefits, subject to physical and institutional constraints. Different types of constraints and mass balance are applied for different nodes. Thus, the operation of the hydrological system is driven by the economic objective of water use, environmental, physical, and legal constraints [36]. The general algebraic modeling system (GAMS) is a high-level modeling language for mathematical programming problems (linear and non-linear programming problems). The GAMS language is especially useful for modeling large and complex problems, that involve many variables and restrictions, as well as high degrees of non-linearity [33].

\subsection{Algebraic Formulation of the Optimization Model}

\subsubsection{Supply Nodes}

Given 1 nodes of demand $l \in \mathrm{L}$, $\mathrm{n}$ nodes of supply $\mathrm{n} \in \mathrm{M}$ and $\mathrm{k}$ nodes upstream of supply $\mathrm{k} \in \mathrm{M}$. Among supply nodes we have two types ( $\mathrm{n} 1$ are the reservoir nodes and $\mathrm{n} 2$ are the river nodes (stream)), with different balance equations, where $\mathrm{n} 1 \mathrm{U} \mathrm{n} 2=\mathrm{n}$. For both supply nodes we have the calculation of the water budget to each of them in each time period year $(y)$ and month $(m)$ given by Equation (1):

$$
\begin{aligned}
& \operatorname{Inflow}(n, y, m)=\sum_{k \in M} \operatorname{Release}(k, y, m) \\
& +\sum_{l \in L} \operatorname{ReturnFlowUpstream}(l, y, m)+\operatorname{Runoff}(n, y, m) \\
& -\sum_{l \in L} \operatorname{Div}(l, y, m)
\end{aligned}
$$

where Release are upstream discharges from supply nodes $\mathrm{k}$ which contribute to supply node n, Div are diversions to demand nodes and Runoff is the contribution of its own incremental watershed (flow associated with the incremental watershed between the node in question and upstream nodes), and values are given automatically per month and year regionalizing hydrological model results for watersheds associated with the supply node. The return flow of allocated water is given by the variable ReturnFlowU pstream, for many uses, especially for irrigation nodes, the return values are high and can be relevant for 
downstream demands. The return flow is proportional to the allocation made to the node and calculated using a user provided factor (percentage) for the demand node.

For a simple node, which represents the section of a river, the water balance is given by Equation (2).

$$
\text { Inflow }(n, y, m)=\operatorname{Release}(n, y, m)
$$

Equation (2) means that, for each stream section node, all the affluent water will be released to the next supply node, considering the water budget (Equation (1)), which contains, for example, diversions (Div) for user nodes.

The reservoir node water balance (Equation (3)) shows the mass balance of an reservoir, considering the change in reservoir volume from one month to the next, as well as the evaporation that is a function of the reservoir area:

$$
\begin{aligned}
\operatorname{RStorage}(n, y, m) & \\
& =\operatorname{RStorage}(n, y, m-1)+\operatorname{Inflow}(n, y, m) \\
& -\operatorname{Release}(n, y, m)-\operatorname{Evaporation}(n, y, m) \\
& * \operatorname{RArea}(n, y, m)
\end{aligned}
$$

The water surface area is related to the volume stored in the reservoir. Maximum and minimum storage; initial and final volume of each reservoir are also represented in the model through constraints, which limit the upper and lower volume of the reservoir, as well as determine initial and final conditions of the reservoirs. See also Figure 4 in the Results section, which shows the editings of a reservoir for the case study.

\subsubsection{Demand Nodes}

Demand nodes are connected to supply nodes, which have in addition to monthly/yearly water demands of the user, economical water values associated. To measure the economic benefits of users associated with the amounts of water allocated in the hydro-economic model, demand curves are used for each use. As each point on the demand curve measures the marginal benefit of a given water availability, areas under the curve estimate the total benefits lost or gained due to a reduction or increase in availability, respectively. It is important to mention that this type of analysis is limited to calculating the economic benefit obtained directly for the user and not considering indirect effects, such as benefits in the users production chain, or other side effects, such as social benefits for the region.

\subsubsection{Point Expansion Method}

The demand curves can be expressed as follows [37]:

$$
P(Q)=e^{\ln \left[\left|Q-C_{2}\right|\right]^{\frac{1}{\eta}}+C_{1}}
$$

where $P$-Water value in $\mathrm{R} \$ / \mathrm{m}^{3}, Q$-Amount of water that can be made available to each user in $\mathrm{m}^{3}$ in the year, $\eta$ - price elasticity of demand (dimensionless) and $C_{1}, C_{2}$-Arbitrary constants (to be defined by boundary conditions).

The allocated water $(\operatorname{Div}(l, y, m))$ for each consumption use or demand node can be fixed by prioritizing a use, for example, but in general it constitutes the decision variable that will receive the optimum allocated amount according to the chosen optimization criteria.

\subsubsection{Links}

The network topology is created by using logical connections of demand and supply nodes, the HEAL systems assures that connection, direction, and logic is maintained. The network topology is not provided by the ArcGIS Geometric Network, the HEAL system creates its own topology, already relating to the translation for the algebraic optimization problem. 


\subsubsection{Objective Function}

The objective function (OF) can be constructed/defined by the user. In the case study, the OF minimizes the scarcity cost for irrigation sites, small farmers and human consumption, as well as the difference between energy production and the guaranteed energy production for each hydropower plant with the PLD (Settlement of Price Differences). At the same time, the objective function maximizes the economic benefit of energy production. Equation (5) shows the used objective function (OF).

$$
\text { OF }=\operatorname{Minimize}\left(\begin{array}{c}
\sum_{n \in \text { pi }} \sum_{a} \sum_{m} C_{n, a, m}+\sum_{n \in \text { id }} \sum_{a} \sum_{m} C_{n, a, m}+\sum_{n \in a h} \sum_{a} \sum_{m} C_{n, a, m} \\
-\sum_{n \in \text { ener }} \sum_{a} \sum_{m} B_{n, a, m}+\sum_{n \in \text { ener }} \sum_{a} \sum_{m}\left(E_{\text {secured }(n)}-E_{n, a, m}\right)^{2} \cdot P L D
\end{array}\right)
$$

where: $n$ (user), $p i$ (irrigation sites), id (small farmer), ah (supply), ener (energy), $C=$ scarcity $\operatorname{cost}[\mathrm{R} \$], B=$ benefit user $[\mathrm{R} \$], E=$ energy [MW] $a, m=$ year, month, and $P L D=$ settlement of price differences.

Scarcity costs (C) of water consumption used in Equation (5) are calculated by using the demand curves (Equation (4)), approximated from the economic values obtained by point expansion method/PMP, using a polynomial regression, with $\mathrm{Q}$ being the amount of allocated water (Equation (6)):

$$
C(Q)=\int_{Q_{\text {aloc }}}^{Q_{100}} \sum_{k=0}^{4} a_{k} Q^{k} d Q
$$

In the hydro-economic model, the gross benefit lost between the quantity allocated and the total demand is used to calculate the scarcity cost, by integrating the demand curves. Benefits for energy production (B) in the equation are calculated directly by using the hydraulic head, turbine specific head losses and energy prices (PLD).

\section{Results}

In the present work, the HEAL system was used, analyzing the economical optimum water allocation and trade-offs for different water uses, focusing on inter-basin water transfers in the São Francisco River Basin-Brazil. Figure 2 shows the interface of the HEAL system and the algebraic formulation of the model in GAMS notation.

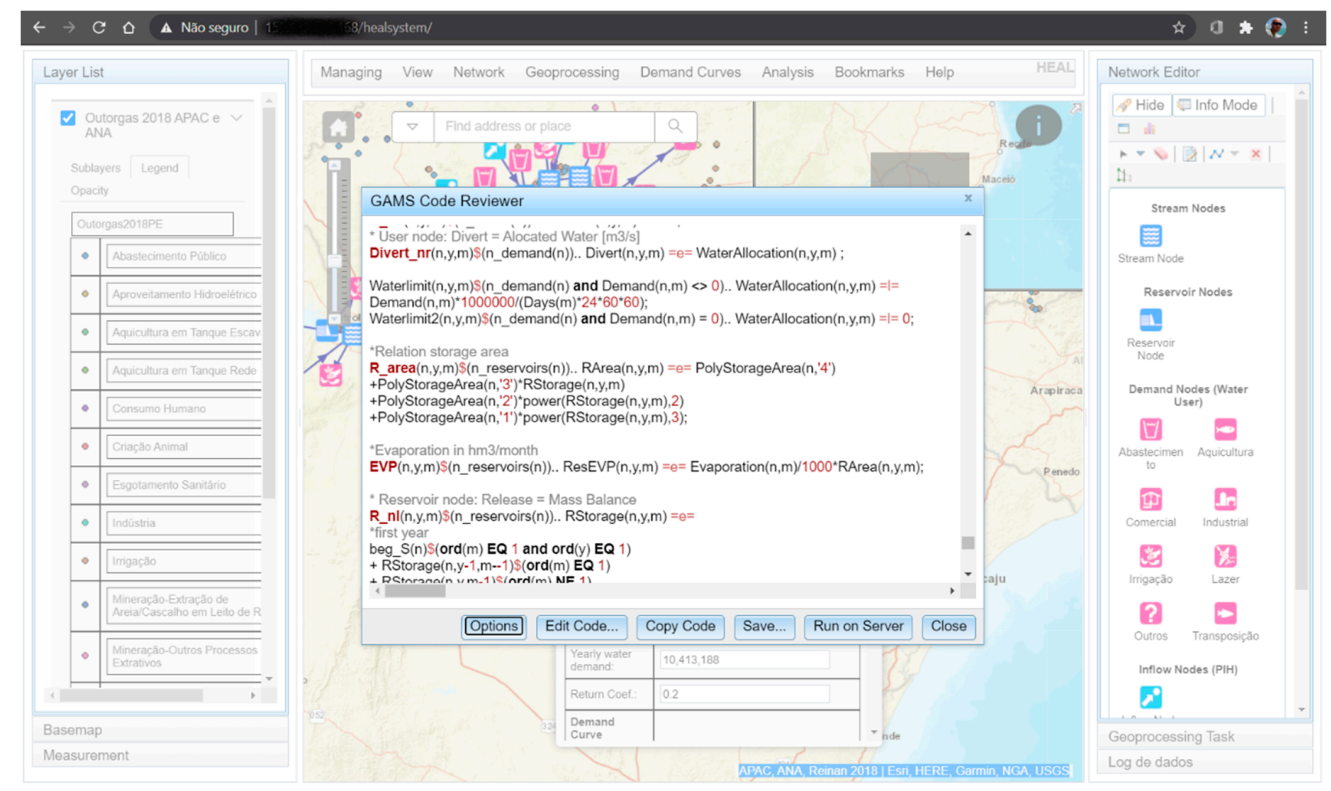

Figure 2. Mathematical programming model (GAMS) of the study area created using HEAL system. 
The user can edit, run, or save the GAMS code, which allows him/her to directly manipulate the solution of the allocation problem. Additional restrictions, functions or objectives, that are not provided by the HEAL System, can be easily incorporated and analyzed using the code editor. Furthermore, the objective function can be selected by the user under Options. Result of the hydro-economic model obtained through SDSS and GIS integration can be found in the case study below.

\subsection{Case Study Description}

The São Francisco River Basin provides approximately $70 \%$ of the surface water for the Northeast of Brazil. About 95 percent of the irrigation projects in NE region use surface water diverted from the regional rivers, particularly the São Francisco River. The basin takes up about $8 \%$ of Brazil's area, and the river has an average annual flow of about 3000 cubic meters per second. The basin has a diverse ecosystem with average temperatures ranging from $20{ }^{\circ} \mathrm{C}$ in the center-southern portion of the basin to $26^{\circ} \mathrm{C}$ in the northeastern areas. The rainfall rates also differ both seasonally and in the different areas. Because of these differences, policy makers and institutional researchers have divided it into four hydrographic sub-regions: from the highlands, through a middle region and then a sub-middle region, to the ocean, sea level.

The sub-middle section of the São Francisco River is a sub-catchment of the São Francisco river basin, located in the Brazilian semi-arid region, which has unique characteristics, especially regarding climate and vegetation. The semi-arid climate is characterized by the regime and the amount of rainfall $(<600 \mathrm{~mm} /$ year), determined by scarcity, spatial irregularity and concentration of rainfall, in addition to high evapotranspiration rates and intermittent rivers. Compared with other physiographic regions, the sub-middle (SM) region contributes to water availability in the region with an inflow of approximately $4 \%$, while its demand is $33 \%$ of the whole basin. Related to the water uses/users, there is a history of a series of conflicts in that region. The most important conflict used to be between electricity generation and irrigated agriculture. There are important and large reservoirs built for electricity generation and are very important to control the river (to avoid floods and ensure navigation) and generate hydro energy for the region. The SM region also includes a highly diverse agricultural system that includes well-capitalized export-focused enterprises, medium- and small-scale commercial farmers and semi-subsistence farmers. Furthermore, two major channels, one called Eixo Leste and the other Eixo Norte, are being built to guarantee water supply outside of the donor basin (water withdrawn from SM region), providing water for the semi-arid region in four States in the Northeast of Brazil (São Francisco River Transboundary Project PISF).

Figure 3 shows the case study location in the Northeast of Brazil and the main hydropower reservoirs: Sobradinho $\left(34,117 \mathrm{hm}^{3}\right.$ storage with installed hydropower capacity of $1.164 \mathrm{MW})$ and Itaparica $\left(10,782 \mathrm{hm}^{3}\right.$ storage with a capacity of $\left.1.664 \mathrm{MW}\right)$. In addition to the hydroelectric plants installed in the Sobradinho and Itaparica reservoirs, the Paulo Afonso complex downstream, has an installed capacity of $4.283 \mathrm{MW}$ in the study area $[38,39]$. Several large Public Irrigation Schemes (PIS) are located in the study area, the largest one, Nilo Coelho, has an irrigated area of 23,486 hectares. 


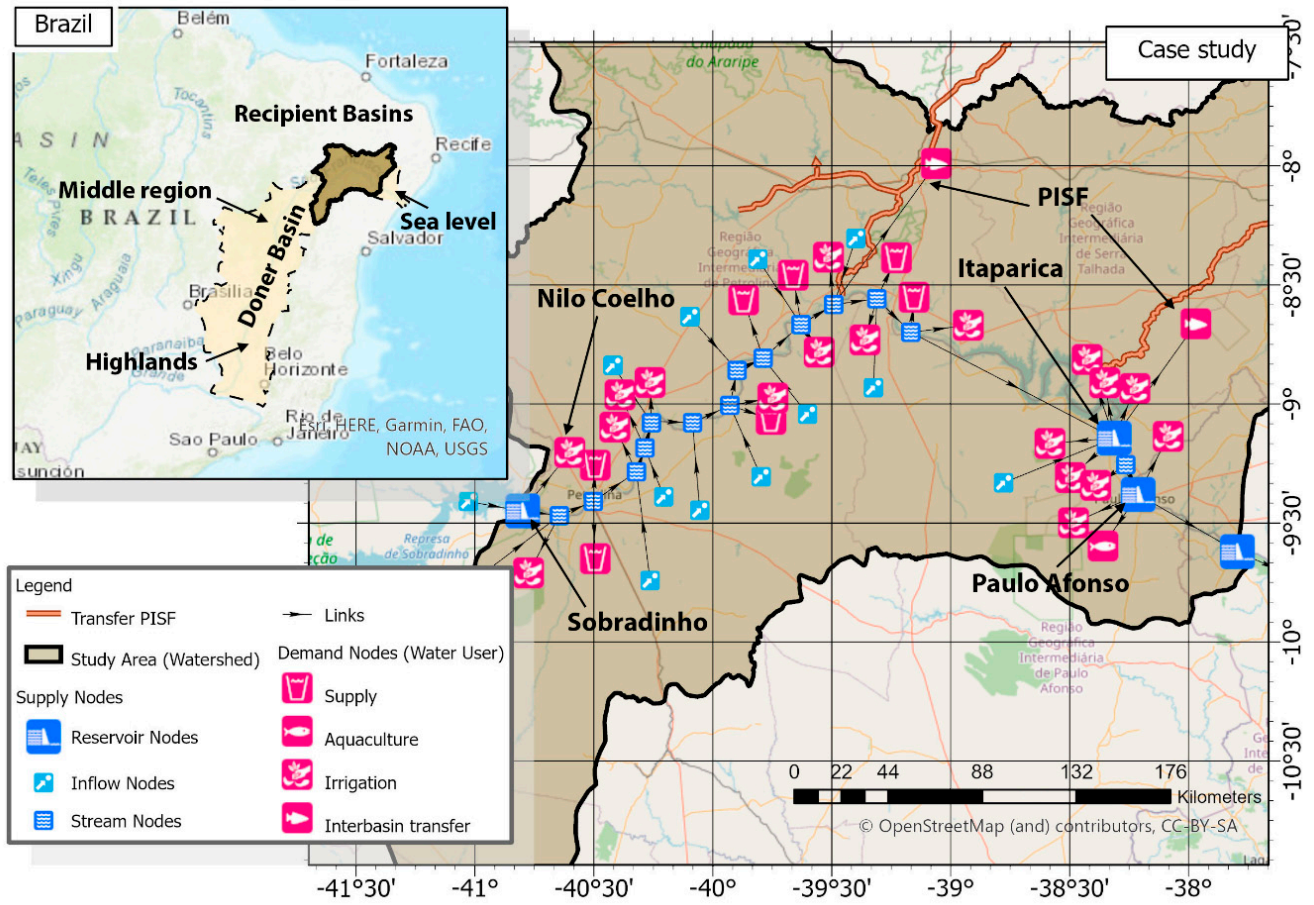

Figure 3. Case study with supply and demand nodes (using the print option of HEAL System).

As the climatology and hydrology of the case study are associated with a high irregularity of the water supply, different water availability scenarios and demand were simulated to obtain optimum values under varied climatic conditions, focusing on years with below-average water availability. The case study framework used a modeling framework developed in the INNOVATE project [40], in which different models are connected, through an approach where the results of the larger scale model are transferred to models with a smaller scale. The HEAL system uses the results of other models as input data, e.g., scenarios, hydrology, changes in land use and climate change that have been obtained from other researchers. In this case study, the main input data is from the model of Agricultural Production and its Impact on the Environment MAgPIE [41,42] and the Soil and Water Integrated Model-SWIM [43]. Hydro-economic modeling requires data regarding water availability for the study area. To model the rainfall-runoff relationship considering scenarios of anthropogenic changes, such as climate change and land-use change, the Soil and Water Integrated Model SWIM $[43,44]$ was used and applied in the basin of the São Francisco river. A diagram to illustrate the framework of the case study can be found in Appendices A and B.

To analyze future anthropogenic changes, the scenarios proposed by SiegmundSchultze et al. $[45,46]$ were used. The first scenario, Baseline, assumes that the conditions (demand, land use, climate) would remain constant (the base year 2000-2006). In the Climate Variability (CV) scenario, climate variability impacts are analyzed using an intense drought period, from 2012-2016. The third scenario, called Fragmentation, is based on the SRES scenario A2 [47], representing high economic and population growth combined with rich and developing countries. The fourth scenario, Global Consciousness, is based on the SRES scenario B1 [47] and simulates globalization, focusing on environmental awareness, leading to lower population growth and sustainable economic growth.

For the scenarios, climate models developed under the framework of the CMIP5 of the World Climate Research Program [48] were used. Five Earth System Models (HadGEM2-ES, IPSL-CM5A-LR, MIROC-ESM-CHEM, GFDL-ESM2M, NorESM1-M) which have been biascorrected using a trend-preserving method [49] were analyzed, and two of the runs have been chosen as climate drivers because they are representative for a dry and wet future in the study area (dry: MIROC_RCP2.6 and wet: HadGEM_RCP8.5). The selection was made 
in such a way that the bandwidth (minor/major changes in temperature or precipitation) was covered. For the Fragmentation (A2) scenario, the model that shows noteworthy changes is HadGEM model (RCP8.5) [50], which points to an increase in precipitation in the study area, with a relative high increase of temperature (A2: $+1.32 \mathrm{~K} \&$ RCP8.5: $+1.35 \mathrm{~K}$ up to year 2050). The other scenario, Global Consciousness (B1), is similar to RCP2.6, in which case the models project smaller changes regarding temperature (B1: $+0.76 \mathrm{~K}$ and RCP2.6: $+0.75 \mathrm{~K}$ ) and a decline in precipitation up to the year 2050, for this dry scenario, the model MIROC (RCP2.6) model [51] projects a temperature increase of about 1 Kelvin in 100 years. The climate models mentioned above are executed with the established scenarios (A2 and B1, respectively). For the case study, seven-year periods are simulated focusing on the near future (up to the year 2050). The influence of these scenarios on water resources can also be found in Koch et al. [52].

\subsection{Hydro-Economic Model Results for the Case Study}

Figure 4 shows the developed interface of the HEAL system and the discretization of the case study. Nodes can be added using the editor on the right, by simply putting the node on the map, the data (hydrological and economic attributes) can be changed by selecting the specific node. Figure 4 shows, as an example, the edition of the information related to a reservoir node. The nodes can also be moved and rearranged (network topology is maintained).

User nodes can be related to water permits in this case the user node data is partially obtained and updated by provided data (services) from the national information system of water resources (SNIRH/ CNARH) [53]. Hydrological data can be integrated using existing or created data through fluviometric data services. In the same way as in demand nodes, existing hydrological information can be linked interactively to inflow nodes. A further advantage of the system is that multiple users can view and edit a project simultaneously, for example, a hydrologist and an economist.

The network will make it possible to integrate the hydrological and economic information of each of the demand nodes. Related to these latter nodes, in addition to presenting the information from the SNIRH/ CNARH database water rights, HEAL also allows the modeler, through geoprocessing tools, to associate these rights with the supply nodes, whose balance is affected for its withdrawals. This network of nodes and links is the main structure of the generated hydro-economic model since it is a network-based model.

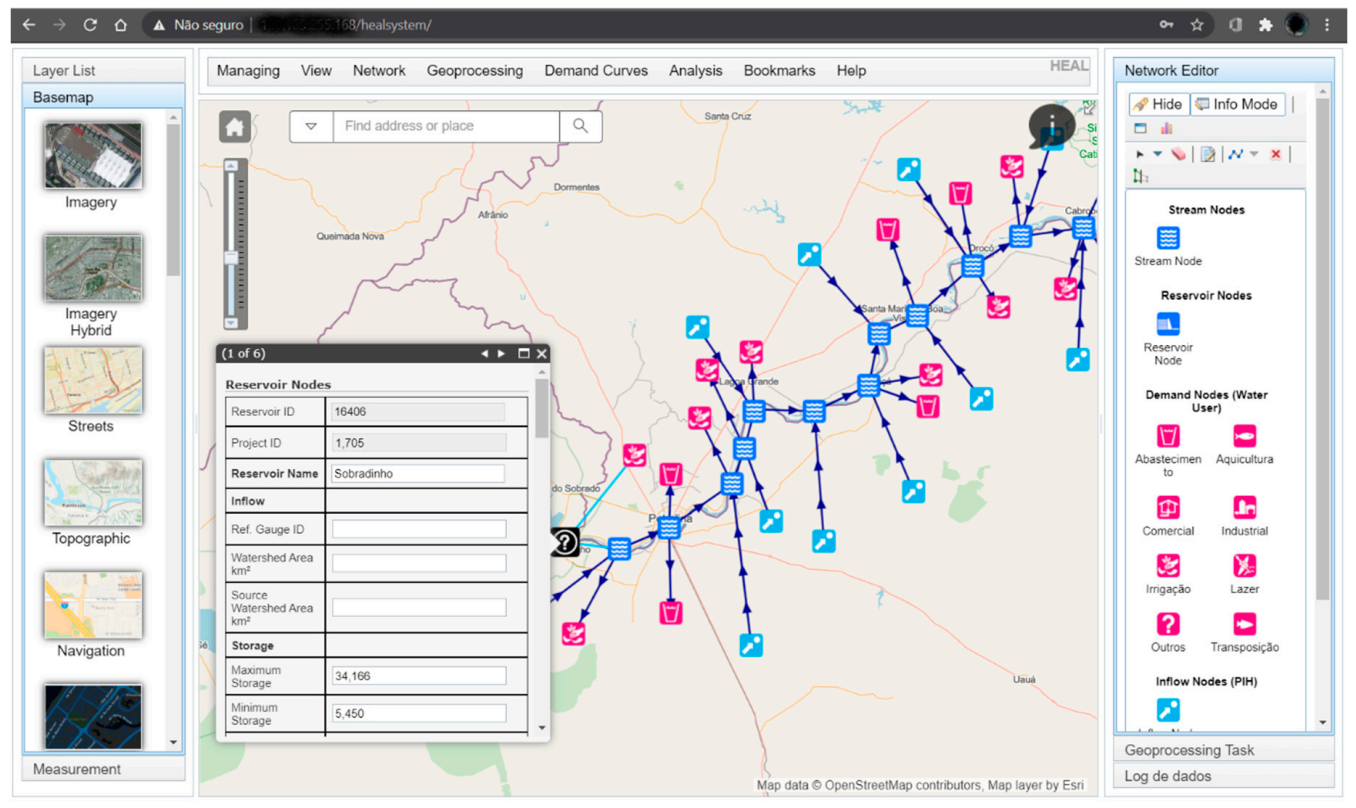

Figure 4. Interface HEAL system with node editor and attribute popup for reservoir node. 
The marginal benefit curves and the resulting benefit functions were obtained for irrigated agricultural production along the river (small farmers) and all municipalities in the Sub-Middle of the São Francisco river basin using scenarios [54]. Demand curves for public irrigation schemes (PIS) were obtained by using Positive Mathematical Programming (PMP). Concerning changes in soil use and climate change, MAgPIE global data [42] was used for the SRES projections [55] and the RCPs [56]. To obtain the marginal benefit curves for the future, regionalization and downscaling of regional and global data was used [57].

The São Francisco river transboundary project (PISF) is currently in the final phase. The point expansion method was used to obtain the demand curves for this water use [37,58,59], with estimates of the associated costs and benefits. For the reference (Baseline) and Climate Variability (CV) scenario, the minimum flow granted by ANA [60] was used as the upper water transfer limit. In scenario A2 (fragmentation), the maximum allowable capacity for the two axes and in scenario B1 the average flow of the two axes was used. The yearly marginal benefit curves for PISF were obtained using the same soil use patterns, crop mix and production values as in the donor basin, limiting the water to current and future demands, together with technical restrictions of the two channels.

Regarding the transfer costs, the reference charges were considered for the provision of the PISF water transfer service [61], which resulted in relatively high charges of 0.204 $\mathrm{R} \$ / \mathrm{m}^{3}$ for fixed cost and $0.303 \mathrm{R} \$ / \mathrm{m}^{3}$ for variable costs. Figure 5 shows the marginal benefit curves obtained for the two channels (axes) (Eixo Norte and Eixo Leste) in different scenarios. All curves are included in the code generated by HEAL system using polynomial regression coefficients of the obtained curves. Other data regarding the HEAL system and PISF is given in Appendix C.
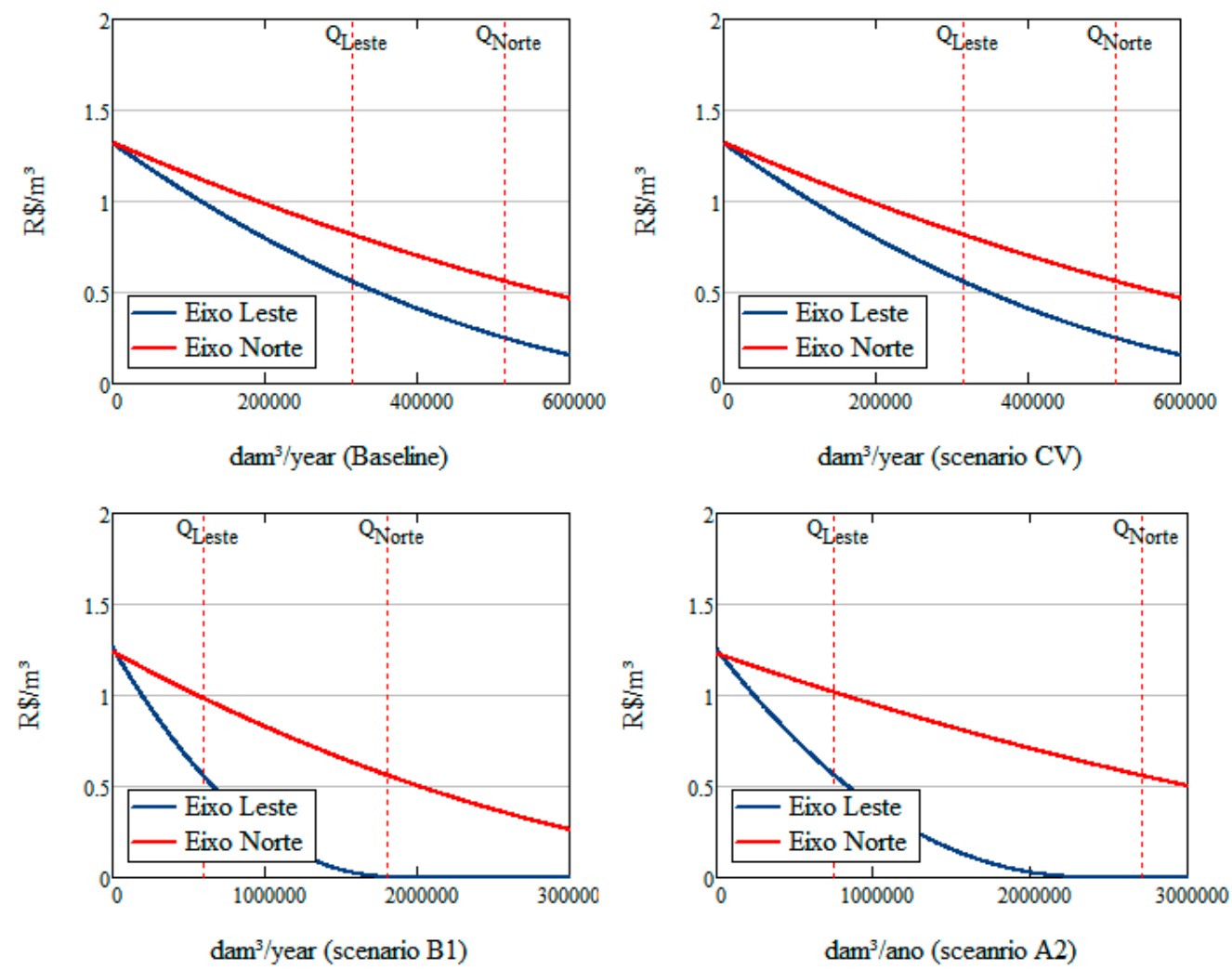

Figure 5. Marginal Benefits Curves for the PISF (transboundary project) under different scenarios (vertical dotted lines: upper bounds/water rights).

The comparison of the main water use sectors, in different scenarios, shows that small farm irrigation can maintain higher percentages of allocated water concerning the demand of other water uses. It should be noted, that neither the amount of water demand nor the 
mix of crops for small farm irrigation were not altered in the scenarios, i.e., no changes were considered in land use patterns for small farm irrigation. On the other hand, some PIS with lower marginal benefits decrease the total water allocation for these users. It is known that each water use sector considered here consists of several agents that use water with different management and efficiency. Some of the marginal benefits analyzed in this work used the average of each sector/water use. Aggregated analyses are necessary mainly because of data insufficiencies and the water resources management policies adopted in Brazil (water pricing for each specific sector), and this may hinder the application and effectiveness of some management instruments/incentives. Figure 6 shows the comparison of different water uses in the simulated scenarios.

One of the major present and future water uses in the case study is the PISF (transboundary project), which was greatly impacted the model results. The results for this special water use will be discussed in more detail. In the Baseline scenario, the PISF obtained $100 \%$ water allocation during the whole period. In dry scenarios (CV, B1), the average water allocation to the axes was less than $50 \%$. The humid (A2) scenario, with agriculture expansion in the donor and recipient basins, showed a relatively high allocation (>90\%) during the whole simulated period; during dry years, however, the water allocation was highly reduced. Figure 6 shows the water allocation percentage to the PISF in the simulated scenarios. The demand curve for the PISF has a relatively high marginal benefit for $100 \%$ of the water allocated, but marginal benefits grew little for the less allocated water quantities (Figure 5). This resulted in a trade-off between water uses in the donor and recipient basins, being more intense in dry scenarios, favoring consumptive uses in the donor basin. The water allocation for the PISF affects all users in the donor basin, mainly in dry scenarios. In addition to reducing benefits to hydropower plants, PIS have higher scarcity costs with the integration of the PISF. Figure 7 shows the difference in benefits/costs for hydropower and consumptive uses in each scenario.

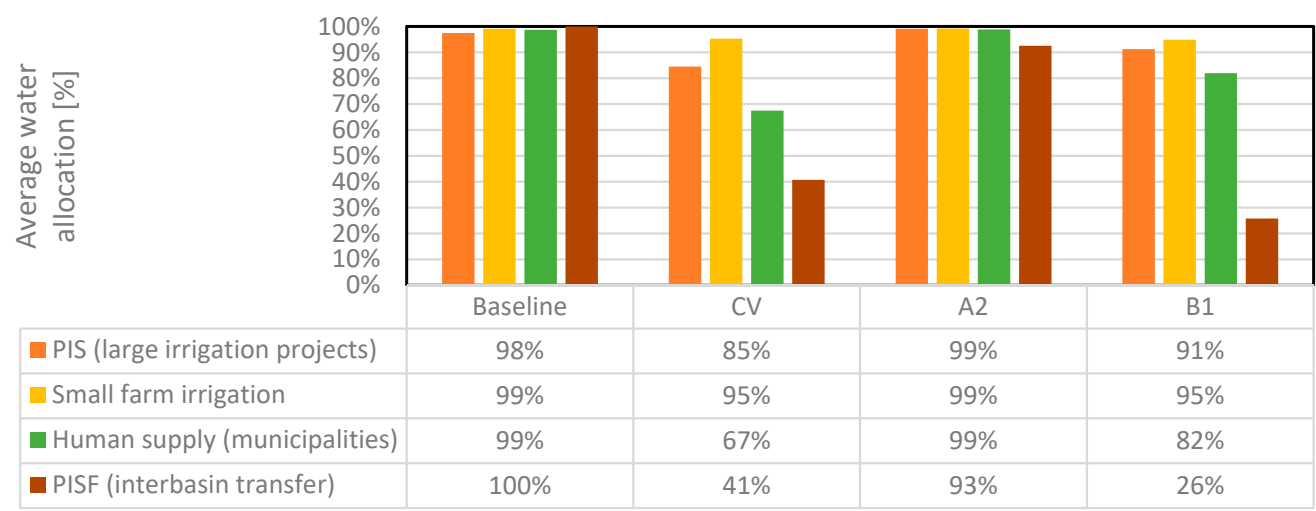

Figure 6. Water allocation of the consumptive uses of water in the scenarios: Climate Variability (CV), Fragmentation (A2), Global Consciousness (B1).

It is observed that the main trade-off of the water allocation for the PISF, in absolute values, is between the irrigation projects and the hydroelectric production in the donor basin. In scenario A2, which represents an expansion of the irrigated areas in the donor and recipient basins, the scarcity costs increased for both basins, $\mathrm{R} \$ 1.32$ billion for the receiver basin and $\mathrm{R} \$ 100.5$ million for the donor basins (considering only consumptive water uses). Optimal water allocations resulted in $100 \%$ of the required water during regular periods (average runoff). In contrast, during dry periods and in critical periods the quantity allocated was reduced to sustainable levels to maximize the benefits in the donor and receiver basins (extended basin), considering the limited water availability and ecological/institutional constraints (ecological river flow). Figure 8 shows the reduced allocation to the PISF during a dry year (2035) in scenario A2 and normalized to $100 \%$ of the demand allocated in years with above average runoff. 
In contrast, Figure 9 shows the water allocation for PIS in the donor basins (Nilo Coelho, Salitre, Icó Mandantes and Tourão), small farm irrigation in the municipality of Lagoa Grande and the water supply of the municipality of Petrolina. The figure shows the same period as in Figure 8 for the scenario A2 and indicates that water allocation in the dry year (2035) is much higher for the uses in the donor basin than the PISF. The irrigation projects Salitre and Tourão had $100 \%$ of their demand allocated under an optimal economic solution. One explanation for the higher allocation for the Salitre irrigation project related to the Nilo Coelho irrigation project is its location. Nilo Coelho withdraws water from the Sobradinho hydropower reservoir, therefore competing more with electricity production than the Salitre irrigation project, located downstream from the reservoir. In addition, the economic values of the projects are differentiated, due to the differentiated mix of crops, mainly, in relation to the quantity of sugarcane, which will increase greatly under the future A2 scenario.

Thus, the optimal economic allocation shows efficient use of the resource, using the marginal benefits for the users in the extended basin. It should be noted that the greater allocation of water to PIS with an increased amount of sugarcane production mirrors the elevated economic values of water associated with sugarcane production due to its relatively low water costs, even with high amounts of water required. These elevated economic values of water associated with irrigated sugarcane production in the basin should continue to provide particular economic incentives to the PIS for the expansion of irrigated sugarcane areas unless water allocation instruments are designed in order to change these water values to avoid conflicts and unsustainable development in the future.
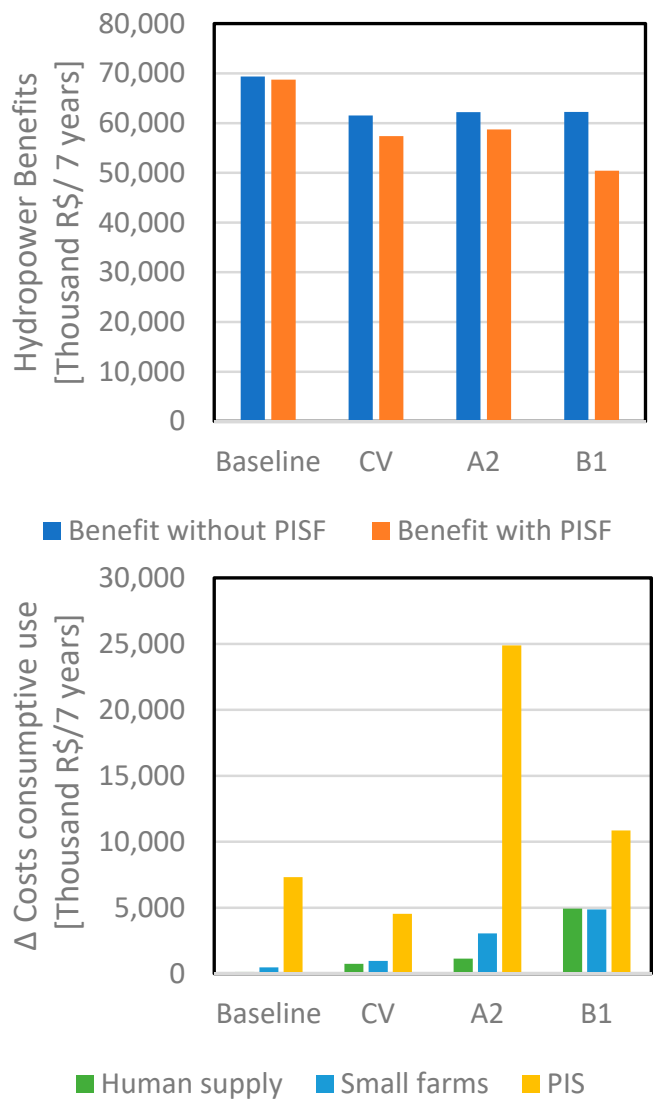

Figure 7. Difference in the benefits of hydroelectric plants and the costs of consumptive uses (Public Irrigation Schemes (PIS), small farms, human supply) in the donor basin with and without PISF (transfer project) in the optimal solution scenarios: Climate Variability (CV), Fragmentation (A2), Global Consciousness (B1). 


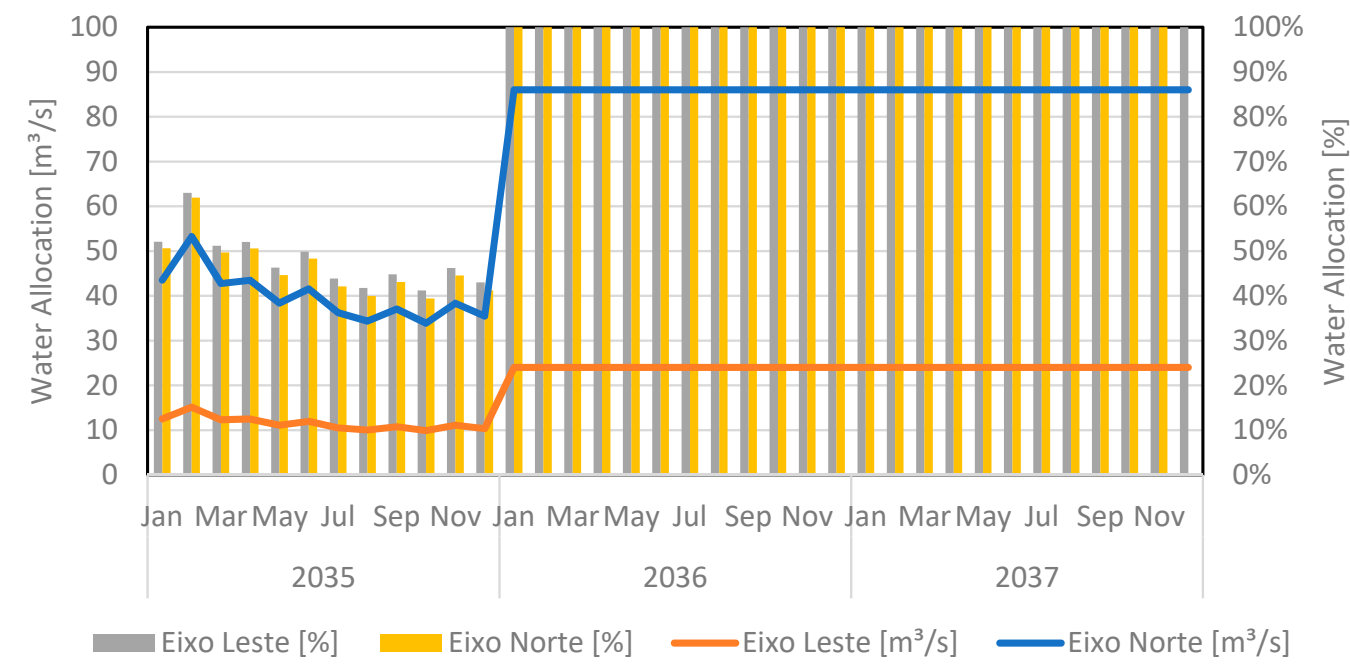

Figure 8. Allocation of water to the PISF (water transfer project) in scenario Fragmentation (A2).

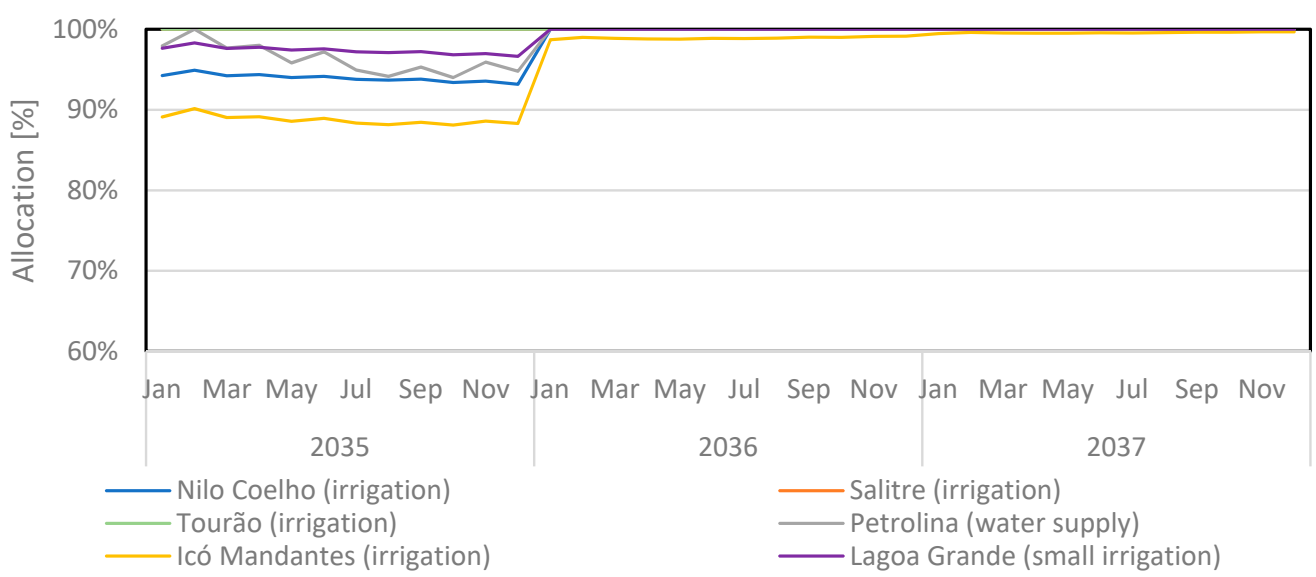

Figure 9. Optimization for water users in donor basin Water Allocation in scenario A2 period 2035-2037 irrigated projects, small irrigation, human supply.

\section{Discussion}

It is important to recognize that the inclusion of the economic criterion adds new theoretical concepts and a complexity beyond that used in traditional water management models, which certainly makes it difficult for managers to accept this approach [10]. The implementation of effective and sustainable instruments needs a planning and decision process which includes the participation of all involved stakeholders. Furthermore, should be done with support of models and DSS that promote negotiation and cooperation [62]. DSS providing hydro-economic models results, are more than ever an important research study area in the field of IWRM, as they can provide common framework for modelers, decision-makers and stakeholders. The resulting economic-decision tools and results available can be effectively used for setting water stakeholder engagement activities all over the world, and particularly in developing countries.

The HEAL system results showed that hydro-economic modelling can be used in practice, using as an example the transboundary project (PISF), which until now has not had operational rules established by the state regulatory agencies in Brazil. The trade-offs must be analyzed using the economic benefits for the donor basin and receiver basins, considering water demands and water availability. The marginal benefit function obtained for the PISF, with higher water costs in comparison to uses in the donor basin, showed that the amount allocated under the optimal economic solution would decrease drastically in dry periods, unlike the water for irrigation used in the donor basin, where the efficient solution maintains a relatively 
high allocated amount of water. This could be a basis for supporting the design of water pricing during periods of scarcity for both these uses within the donor basin and the water transfers. Currently, water prices established in Brazilian basins have little impact on the water uses and the amount consumed by each use, especially for water used for irrigation [63-65]. However, to encourage the rational use of water, in the regions of greater aridity, where water is scarce, the water price needs to reflect the scarcity of this resource. This is a given in the model for the PISF when considering high transfer costs in its marginal benefits functions, which resulted in a lower optimal economic allocation. This same allocative mechanism (charging) can be used by the water resource manager to reduce other external or internal demands and lead to efficient use of the transferred water.

Especially under challenges such as global climate and socio-economic changes [66], the use and understanding of the hydro-economic models is important, since they have the potential to influence participant beliefs and perceptions towards transformative thinking about critical water sustainability issues. This could broaden the policymaker's and stakeholder's view as far as choices for an effective water policy to implement the desired IWRM and promote environmentally sustainable economic development.

Currently, the São Francisco river basin plan [51] limits the grantable flow of $360 \mathrm{~m}^{3} / \mathrm{s}$ for the whole basin. The results show that even with greater water availability in the A2, compared to the $\mathrm{B} 1 / \mathrm{CV}$ climate and socio-economic change scenarios, demand exceeds the allowable flow rate in some years, which implies the need for efficient water allocation strategies incorporating environmental, institutional, and policy constraints. To limit water use, in a context of sustainability, it is necessary to use management instruments that signal the scarcity to the diverse economic agents/users of water. If appropriately designed, water demand policies must be capable of enhancing a more efficient inter- and intra-sector water allocation scheme, ensuring the sustainability of water use while, at the same time, promoting economic development.

\section{Conclusions}

With the Agenda 2030 objective [67] to substantially increase the efficiency of water use and guarantee sustainable withdrawals to address the scarcity of resources in mind, it is necessary to create policies regarding irrigated projects and other types of use with less economic efficiency. Water scarcity is often an institutional responsibility due to deficiencies in the application of regulatory and economic instruments. Supply management (with expansion to storage and distribution infrastructure) does not necessarily ensure and increase water availability. The supply management can only transfer water in space and time, and even more, it can lead to an increase in water loss, e.g., through evaporation. Arid regions need supply management with mechanisms to regulate the amount of water offered. This strategy is known as demand management and is implemented through regulatory and economic instruments, such as pricing, water permits, basin plans, environmental and institutional restrictions. Furthermore, such a strategy is likely to increase the revenues for a region, as shown by Forni et al. [68].

The developed SDSS (HEAL system) made the economically optimum allocation available to analyze water allocation conflicts and trade-offs. With the aim of providing a tool for integrated economic-hydrological modeling, not only for researchers but also for decisionmakers and stakeholders, the HEAL system can support decision-making on the design of regulatory and economic management instruments in practice. The web-interface reduces technical complications for users in analyzing hydro-allocation problems from an economic point of view. The existence of a model or criteria base makes possible to create more than one model (other constraints such as water quality limits) or criterion (for example hydrological criteria to be compared to economic one) as well as analysis of scenarios or sensitivity through an interface for the user/stakeholder. The strong coupling between models and a web-based GIS environment makes the representation of hydrological, environmental and economic aspects possible in a single platform. This should favor future developments of integrating other economic models of water management (economy-wide models) using the 
platform and also of integrating of water quality aspects into economic components. Recent reviews, already mentioned, have stressed not only the need, but the difficulty of those types of integration, in order to support implementation of an authentic IWRM.

Spatial decision support systems increase the potential of applying analytical tools, as greatly facilitate and enhance their use by decision makers and stakeholders, favoring an environmentally sustainable management of water resources. Automated systems that can integrate economic analysis to hydrological are able to support the evolution of IWRM. The design of regulatory and economic management instruments, especially the latter, based on economic-hydrologic integrated modeling results can induce changes in behavior, leading to more effective water allocations among economic sectors, when water is scarce and/or when water quality is poor, especially in countries of continental dimensions and with low enforcement capability.

Author Contributions: Conceptualization, G.N.S.d.S.; methodology, M.M.G.A.d.M.; software, G.N.S.d.S.; validation, G.N.S.d.S.; formal analysis, G.N.S.d.S.; investigation, G.N.S.d.S.; resources, G.N.S.d.S.; data curation, G.N.S.d.S.; writing—original draft preparation, G.N.S.d.S.; writing—-review and editing, G.N.S.d.S.; visualization, G.N.S.d.S.; supervision, M.M.G.A.d.M.; project administration, M.M.G.A.d.M.; funding acquisition, M.M.G.A.d.M. Both authors have read and agreed to the published version of the manuscript.

Funding: Financial support for this research has been provided by ANA/CAPES (16/2017), CNPq (PhD scholarship and CT-Hidro project 35/2013). The authors are participants of the INNOVATE project, which was funded by BMBF in Germany and CNPq/CAPES in Brazil.

Data Availability Statement: Publicly available datasets were analyzed in this study. This data can be found here: https:/ /1drv.ms/u/s!AmEU-u26qeXQge0nNRpwdS2kpsWE0g?e=o37Zef (accessed on 15 February 2021).

Acknowledgments: The authors would like to thank the INNOVATE project team and the Federal University of Pernambuco (UFPE) for the provided framework and contributions.

Conflicts of Interest: The authors declare no conflict of interest.

\section{Appendix A. Additional Model Parameters, Variables, Equations and Restrictions}

Restrictions (Institutional and environmental constraints)

Reference

- Technical restrictions (dam, powerhouse, spillway etc.) [39]

- Flood protection (Restriction)

Table A1. Standby volume [39] RStorage $(n, m)<S V$.

\begin{tabular}{ccc}
\hline SV [\%] & Sobradinho TR $=\mathbf{1 7}$ Anos & Itaparica TR = 20 Anos \\
\hline Jan & 76.91 & 60.74 \\
\hline Feb & 76.91 & 60.74 \\
\hline Mar & 80.43 & 62.10 \\
\hline Apr & 80.73 & 81.39 \\
\hline May & 100.00 & 100.00 \\
\hline Jun & 100.00 & 100.00 \\
\hline Jul & 100.00 & 100.00 \\
\hline Aug & 100.00 & 100.00 \\
\hline Sep & 100.00 & 100.00 \\
\hline Oct & 100.00 & 100.00 \\
\hline Nov & 79.50 & 73.93 \\
\hline Dec & 77.51 & 60.74 \\
\hline
\end{tabular}


In addition, maximum flow rates and maximum flood control level are used as restrictions: a max outflow of $8.000 \mathrm{~m}^{3} / \mathrm{s}$ for Sobradinho and a maximum water level of $304.00 \mathrm{~m}$ in Belém do São Francisco [39]:

$\circ \quad$ Lower bound Sobradinho and Xingo reservoir (environmental demand)

$$
\begin{gathered}
\text { Release (Sobradinho, } y, m)>1.300 \mathrm{~m}^{3} / \mathrm{s} \\
\text { Release }(\text { Xingo, } y, m)>1.300 \mathrm{~m}^{3} / \mathrm{s}
\end{gathered}
$$

Prioritizing human consumption

$$
\operatorname{Div}(n, y, m)=\operatorname{Demand}(n, y, m) \quad n \in \text { supply municipality }
$$

\section{Appendix B. INNOVATE Project Framework}

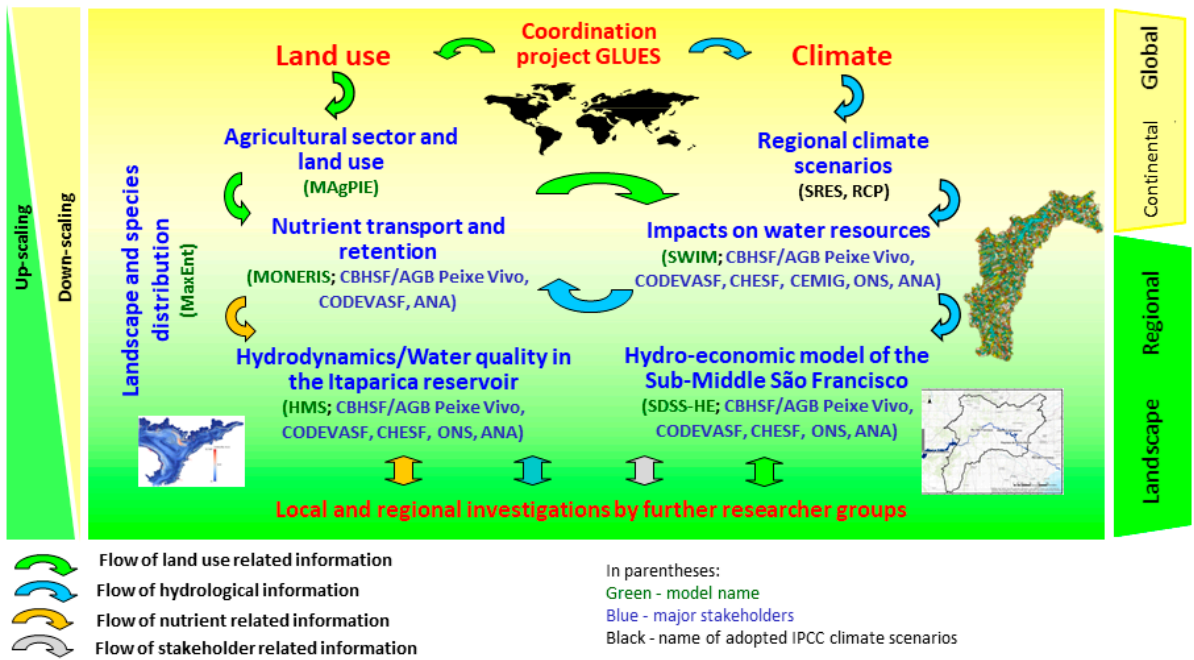

Figure A1. Overview: model chain and flow of information.

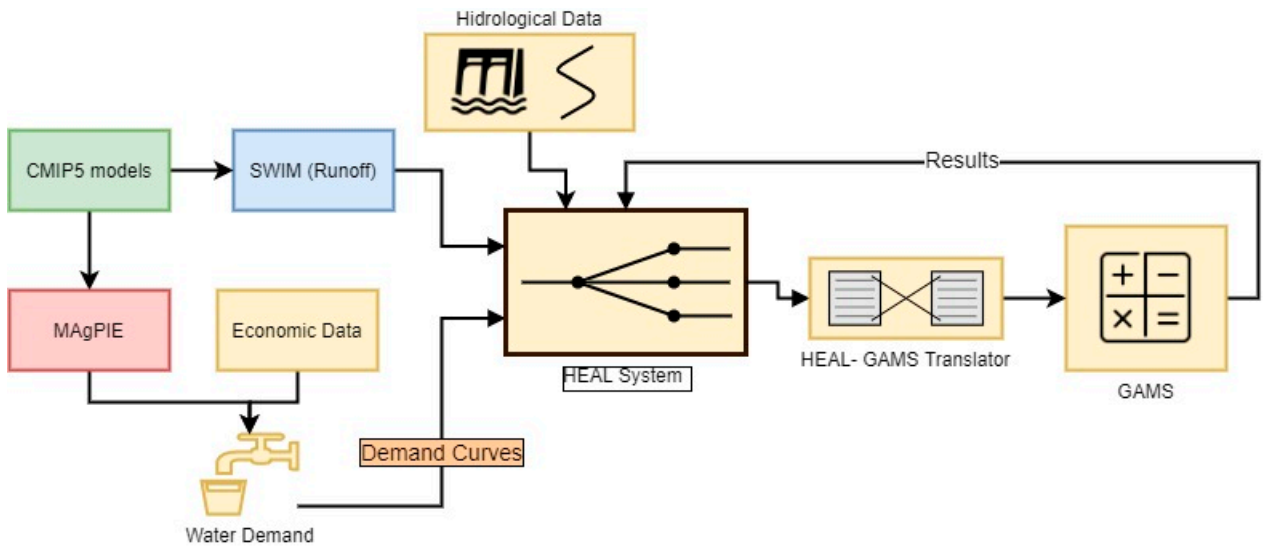

Figure A2. HEAL System: model chain and flow of information.

\section{Appendix C. PISF Inter-Basin Water Transfer}

For the benefit calculations for the water transfer, estimates were used, based on data from the donor basin, such as crop mix and production value. From these data and those related to water use, was obtained (for some municipalities) in doner basin the net benefits for agriculture (irrigation) users given in the following table. 
Table A2. Net benefits for agriculture (irrigation) users.

\begin{tabular}{cc}
\hline Municipality & Net Benefit $/ \mathrm{m}^{3}$ \\
\hline Petrolina & $0.95 \mathrm{R} \$ / \mathrm{m}^{3}$ \\
\hline Cabrobó & $0.83 \mathrm{R} \$ / \mathrm{m}^{3}$ \\
\hline Santa Maria & $0.83 \mathrm{R} \$ / \mathrm{m}^{3}$ \\
\hline Oroço & $0.69 \mathrm{R} \$ / \mathrm{m}^{3}$ \\
\hline
\end{tabular}

Thus, for the uses of irrigated agriculture in the receiving basin, an average value of $0.86 \mathrm{R} \$ / \mathrm{m}^{3}$ was adopted as a benefit. For the domestic uses, the values of the water supply companies of the municipalities in the receiving basins with a positive revenue were used. The average found was $0.91 \mathrm{R} \$ / \mathrm{m}^{3}$. Regarding costs, the reference tariffs (availability and consumption) for the provision of the PISF raw water supply service were considered.

\section{References}

1. Moraes, A.M.; da Silva, G.S. O Papel da Economia na Gestão Sustentável de Bacias Hidrográficas. In Gestão Sustentável de Bacias Hidrográficas; SEAERJ: Recife, Brazil, 2017.

2. Kim, J.Y. The World Bank Annual Report 2019: Ending Poverty. In Investing in Opportunity; World Bank Annual Report; The World Bank: Washington, DC, USA, 2019.

3. Maass, A. Design of Water Resource Systems; Harvard University Press: Cambridge, MA, USA, 1962.

4. Loucks, D.P.; Stedinger, J.R.; Haith, D.A. Water Resources Systems Planning and Analysis; Prentice-Hall: Englewood Cliffs, NJ, USA, 1981.

5. Braat, L.C.; Lierop, W.F.J. Integrated Economic-Ecological Modeling; North Holland Publishing Co.: Amsterdam, The Netherlands, 1987.

6. Mckinney, C.D.; Cai, X.; Rosegrant, M.; Ringler, C.; Scott, C.A. Integrated Basin-Scale Water Resources Management Modeling: Review and Future Directions, SWIM Research Record No. 6 Int; Water Management Institute: Colombo, Sri Lanka, 1999.

7. Cai, X.; McKinney, D.C.; Lasdon, L.S. Solving nonlinear water management models using a combined genetic algorithm and linear programming approach. Adv. Water Resour. 2001, 24, 667-676. [CrossRef]

8. Cai, X.M. Implementation of holistic water resources-economic optimization models for river basin man-agement-Reflective experiences. Environ. Model. Softw. 2008, 23, 2-18. [CrossRef]

9. Mayer, A.; Hernandez, M.A. Integrated Water Resources Optimization Models: An Assessment of a Multidisciplinary Tool for Sustainable Water Resources Management Strategies. Geogr. Compass 2009, 1176-1195. [CrossRef]

10. Harou, J.J.; Velazquez, M.P.; Rosenberg, D.E.; Azuara, J.M.; Lund, J.R.; Howitt, R.E. Hydro-economic models: Concepts, design, applications, and future prospects. J. Hydrol. 2009, 627-643. [CrossRef]

11. Bo, M.M.; Expósito, A.; Berbel, J. A Simplified Hydro-Economic Model of Guadalquivir River Basin for Analysis of Water-Pricing Scenarios. Water 2020, 12, 1879.

12. Maneta, M.; Torres, M.O.; Wallender, W.W.; Vosti, S.; Howitt, R.; Rodrigues, L.; Bassoi, L.H.; Panday, S. A spatially distributed hydro-economic model to assess the effects of drought on land use, farm profits, and agricultural employment. Water Resour. Res. 2009, 45. [CrossRef]

13. Salla, M.R.; Javier, P.A.; Abel, S.; Alvarez, J.A.; Pereira, C.E.; Alamy, F.J.E.; De Oliveira, A.L. Integrated modeling of water quantity and quality in the Araguari River basin, Brazil. Latin Am. J. Aquat. Res. 2014, 42, 224-244. [CrossRef]

14. Chakroun, H.; Chabaane, Z.L.; Benabdallah, S. Concept and prototype of a spatial decision support system for integrated water management applied to Ichkeul Basin, Tunisia. Water Environ. J. 2015, 29, 169-179. [CrossRef]

15. Ghosh, S.; Ibarrarán, M.E.; Willett, K.D.; Esqueda, G.S.T. Water Allocation and Management along the Santa Cruz Border Region. Water Resources and Economics; Elsevier BV: Amsterdam, The Netherlands, 2017; Volume 19, pp. 1-17.

16. Giri, S.; Arbab, N.N.; Lathrop, R.G. Water security assessment of current and future scenarios through an integrated modeling framework in the Neshanic River Watershed. J. Hydrol. 2018, 563, 1025-1041. [CrossRef]

17. Gunawardena, A.; White, B.; Hailu, A.; Wijeratne, E.M.S.; Pandit, R. Policy choice and riverine water qual-ity in developing countries: An integrated hydro-economic modelling approach. J. Environ. Manag. 2018, 227, 44-54. [CrossRef]

18. Kahil, M.T.; Dinar, A.; Albiac, J. Modeling water scarcity and droughts for policy adaptation to climate change in arid and semiarid regions. J. Hydrol. 2015, 522, 95-109. [CrossRef]

19. Ahmadaali, J.; Barani, G.A.; Qaderi, K.; Hessari, B. Analysis of the effects of water management strategies and climate change on the environmental and agricultural sustainability of Urmia Lake Basin, Iran. Water 2018, 10, 160. [CrossRef]

20. Garbe, J.; Beevers, L. Modelling the impacts of a water trading scheme on freshwater habitats. Ecol. Eng. 2017, 105, 284-295. [CrossRef]

21. Bekchanov, M.; Sood, A.; Pinto, A.; Jeuland, M. Systematic Review of Water-Economy Modeling Applications. J. Water Resour. Plan. Manag. 2017, 143, 7037. [CrossRef] 
22. Brouwer, R.; Hofkes, M. Integrated hydro-economic modelling: Approaches, key issues and future research directions. Ecol. Econ. 2008, 66, 16-22. [CrossRef]

23. Manzardo, A.; Loss, A.; Fialkiewicz, W.; Rauch, W.; Scipioni, A. Methodological proposal to assess the water footprint accounting of direct water use at an urban level: A case study of the Municipality of Vicenza. Ecol. Indic. 2016, 69, 165-175. [CrossRef]

24. Castillo, R.M.; Feng, K.; Sun, L.; Guilhoto, J.; Pfister, S.; Wilhelm, F.M.; Hubacek, K. The land-water nexus of biofuel production in Brazil: Analysis of synergies and trade-offs using a multiregional input-output model. J. Clean. Prod. 2019, 214, 52-61. [CrossRef]

25. Sun, Y.; Mao, X.; Gao, T.; Liu, H.; Zhao, Y. Potential water withdrawal reduction to mitigate riverine eco-system degradation under hydropower development: A computable general equilibrium model analysis. River Res. Appl. 2020, 1-8. [CrossRef]

26. Candido, L.A.; Coêlho, G.A.G.; Moraes, M.M.G.A.; Florêncio, L. Review of Decision Support Systems and allocation models for Integrated Water Resources Management focusing on joint water quality-quantity. J. Water Resour. Plan. Manag. 2021. (abstract accepted, full text under revision).

27. GWP. Catalyzing Change: A Handbook for Developing Integrated Water Resources Management (IWRM) and Water Efficiency Strategies; Global Water Partnership (GWP) Technical Committee with support from Norway's Ministry of Foreign Affairs: Stockholm, Sweden, 2004.

28. Braun, J. Policy Nook: 'Expanding Water Modeling to Serve Real Policy Needs. Water Econ. Policy 2016, 2, 1-9. [CrossRef]

29. Momblanch, A.; Connor, J.D.; Crossman, N.D.; Arquiola, P.J.; Andreu, J. Using ecosystem services to represent the environment in hydro-economic models. J. Hydrol. 2016, 538, 293-303. [CrossRef]

30. McKinney, D.C.; Cai, X. Linking GIS and water resources management models: An object-oriented method. Environ. Model. Softw. 2001, 413-425. [CrossRef]

31. Crosbie, P. Object-oriented design of GIS: A new approach to environmental modeling. In GIS and Environmental Modeling: Progress and Research Issues; John Wiley \& Sons: Amsterdam, The Netherlands, 1996; pp. 383-386.

32. McKinney, D.C.; Tsai, H.L. Multigrid method grid-cell-based modeling environment. J. Comput. Civil. Eng. 1996, 10, 80-86. [CrossRef]

33. Rosenthal, R.E. GAMS User's Guide; GAMS Development Corporation: Washington, DC, USA, 2012.

34. ESRI. ArcGIS API for JavaScript 3.23. Available online: https://developers.arcgis.com/javascript/3 (accessed on 24 August 2017).

35. ESRI. ArcMap Geomteric Networks. Available online: http://desktop.arcgis.com/en/arcmap/10.3/manage-data/geometricnetworks / what-are-geometric-networks-.htm (accessed on 24 August 2017).

36. Moraes, M.M.G.A.; Cirilo, J.A.; Sampaio, Y. Joint Water Quantity-Quality Management in a Biofuel Production Area-Integrated Economic-Hydrologic Modeling Analysis. Water Resour. Plng. Manag. 2010, 136, 502-511. [CrossRef]

37. Moraes, M.M.G.A.; Cirilo, J.A.; Sampaio, Y. Integração dos Componentes Econômico e Hidrológico na Modelagem de Alocação Ótima de Água para Apoio a Gestão de Recursos: Uma Aplicação na bacia do Pira-pama. Rev. Econ. 2006, vol. 7, 331-364.

38. FINEP. Technical Report. Convenio FINEP 01.04.0761.00; FINEP: Recife, Brazil, 2007.

39. National Electric System Operator-ONS. HydroData; ONS: Brasil, 2014.

40. Koch, H.; Schultze, S.M. Introduction to Applying Scenarios: A Basis for Innovate's Scenario Approach; FINEP: Recife, Brazil, 2014.

41. Campen, L.H.; Muller, C.; Bondeau, A.; Rost, S.; Popp, A.; Lucht, W. Global food demand, productivity growth, and the scarcity of land and water re-sources: A spatially explicit mathematical programming approach. Agric. Econ. 2008, 325-338. [CrossRef]

42. Biewald, A.; Campen, L.H.; Schmitz, C.; Kölling, K.; Beck, F. The impact of future climate and socioeconomic changes on landuse in the catchment area of the Rio São Francisco. In Proceedings of the INNOVATE Status Conference, Recife, Brazil, 14 October 2014.

43. Krysanova, V.; Wechsung, F.; Arnold, J.; Srinivasan, R.; Williams, J. SWIM (Soil and Water Integrated Model) User Manual; Potsdam Institute for Climate Impact Research: Potsdam, Germany, 2000.

44. Krysanova, V.; Wohlfeil, M.D.I.; Becker, A. Development and test of a spatially distributed hydrolog-ical/water quality model for mesoscale watersheds. Ecol. Model. 1998, 106, 261-289. [CrossRef]

45. Schultze, S.M.; Azevedo, J.R.; Hartje, V.; Koch, H.; Köppel, J.; Alcoforado de Moraes, M.M.G.; Siewert, S. Is the future what it used to be? Scenarios and their impacts on people and ecosystem services in the São Francisco watershed. Round Table 1: Modeling, socioeconomic analysis, and governance for sustainable resource use. In Proceedings of the Innovate Status Conference, Recife, Brazil, 14-15 October 2014.

46. Schultze, S.M.; Köppel, J.; Sobral, M.C. Balancing ecosystem services and societal demands in a highly managed watershed: Setup and progress of a comprehensive research project. Rev. Bras. Ciências Ambient. 2015, 36, 3-18. [CrossRef]

47. Nakicenovic, N.; Swart, R. Special Report on Emissions Scenarios (SRES); Cambridge University Press: Cambridge, MA, USA, 2000.

48. Taylor, K.E.; Stouffer, R.J.; Meehl, G.A. An overview of CMIP5 and the experiment design. Bull. Am. Meteorol. Soc. 2012, 93, 485-498. [CrossRef]

49. Hempel, S.; Frieler, K.; Warzawski, L.; Schewe, J.; Piontek, F.A. Trend-Preserving Bias Correction-The ISI-MIP Approach. Earth Syst. Dyn. 2013, 4, 219-236. [CrossRef]

50. Madec, G.; Imbard, M. A global ocean mesh to overcome the north pole singularity. Clim. Dyn. 1996, 12, 381-388. [CrossRef]

51. Watanabe, S.; Hajima, T.; Sudo, K.; Nagashima, T.; Takemura, T.; Okajima, H.; Nozawa, T.; Kawase, H.; Abe, M.; Yokohata, T.; et al. MIROC-ESM 2010: Model description and basic results of CMIP5-20c3m experiments. Geosci. Model Dev. 2011, 845-872. [CrossRef] 
52. Koch, H.; Biewald, A.; Liersch, S.; de Azevedo, J.R.G.; Silva, G.N.S.; Kolling, K.; Fischer, P.; Koch, R.; Hattermann, F.F. Scenarios of climate and land-use change, water demand and water availability for the São Francisco River Basin. Rev. Bras. Ciências Ambient. 2015, 36, 96-114. [CrossRef]

53. ANA. ArcGIS REST Services Directory. Available online: http://www.snirh.gov.br/arcgis/rest/services/SRE/OUTORGAS_ CNARH40/MapServer (accessed on 21 January 2018).

54. Silva, G.S.; Figueiredo, L.E.; de Moraes, M.M.G.A. Demand Curves for Water Ressources of the main water users in sub-middle São Francisco basin. RBCIAMB 2015, 45-59. [CrossRef]

55. IPCC. Climate Change 2013; Cambridge University Press: Cambridge, MA, USA, 2013.

56. van Vuuren, D.P.; Edmonds, J.A.; Kainuma, M.; Riahi, K.; Weyant, J. A special issue on the RCPs. Clim. Chang. 2011, 109, 1-4. [CrossRef]

57. Moraes, M.M.G.A.; Biewald, A.; Carneiro, A.C.G.; Silva, G.N.S.; Popp, A.; Campen, H.L. The impact of global changes on economic values of water for Public Irri-gation Schemes at the São Francisco River Basin in Brazil. Reg. Environ. Chang. 2018, 18, 1943-1955. [CrossRef]

58. da Silva, G.S. Apoio à Gestão Sustentável de Recursos Hídricos Através de um Modelo Hidro-Econômico de-Senvolvido em Diferentes Cenários de Uso do Solo e Clima: O Caso do Sub-Médio do São Francisco; UFPE: Recife, Brazil, 2017.

59. Griffin, R.C. Water Resource Economics: The Analysis of Scarcity, Policies, and Projects; MIT Press: Cambridge, UK, 2006.

60. ANA. Resolução 411-Outorga PISF de 22 de Setembro de 2005; ANA: Brasilia, Brazil, 2005.

61. ANA. Technical Note Conjunta $n^{\circ}$ 1/2016/COSER/SRE/SAS; ANA: Brasilia, Brazil, 2016.

62. Carrera, B.L.; Warren, A.; van Beek, E.; Jonoski, A.; Giardino, A. Collaborative modelling or participa-tory modelling? A framework for water resources management. Environ. Model. Softw. 2017, 91, 95-110. [CrossRef]

63. ANA. Nota Técnica $n^{\circ} 042$ /2008/SAG-ANA; ANA: Brasilia, Brazil, 2008.

64. Kelman, J.; Ramos, M. Custo, valor e preço da água utilizada na agricultura. REGA 2005, 2, 39-48.

65. Vera, L.H.A. Atuação da Cobrança pelo Uso da Água de Domínio da União como Instrumento de Gestão de Recursos Hídricos na Bacia Hidrográfica do Rio São Francisco; UFPE: Recife, Brazil, 2014.

66. Beier, A.; Berbel, F.; Expósito, J. Economic Modelling for Water-Policy Assessment under Climate Change at a River Basin Scale: A Review. Water 2020, 12, 1559.

67. United Nations. The 2030 Agenda for Sustainable Development; United Nations: New York, NY, USA, 2015.

68. Forni, L.G.; Medellín-Azuara, J.; Tansey, M.; Young, C.; Purkey, D.; Howitt, R. Integrating complex economic and hydrologic planning models: An application for drought under climate change analysis. Water Resour. Econ. 2016, 16, 15-27. [CrossRef] 